\title{
Changing trends in China's inequality: evidence, analysis, and prospects
}

\author{
Document Version \\ Proof
}

Link to publication record in Manchester Research Explorer

\section{Citation for published version (APA):}

Ren, Y. (2020). Changing trends in China's inequality: evidence, analysis, and prospects. Eurasian Geography and Economics.

\section{Published in:}

Eurasian Geography and Economics

\section{Citing this paper}

Please note that where the full-text provided on Manchester Research Explorer is the Author Accepted Manuscript or Proof version this may differ from the final Published version. If citing, it is advised that you check and use the publisher's definitive version.

\section{General rights}

Copyright and moral rights for the publications made accessible in the Research Explorer are retained by the authors and/or other copyright owners and it is a condition of accessing publications that users recognise and abide by the legal requirements associated with these rights.

\section{Takedown policy}

If you believe that this document breaches copyright please refer to the University of Manchester's Takedown Procedures [http://man.ac.uk/04Y6Bo] or contact uml.scholarlycommunications@manchester.ac.uk providing relevant details, so we can investigate your claim.

\section{OPEN ACCESS}


BOOK REVIEW

Changing trends in China's inequality: evidence, analysis, and prospects,
edited by Terry Sicular, Shi Li, Ximing Yue, and Hiroshi Sato, New York, USA,
Oxford University Press, 2020, 456 pp., $£ 64.00$ (hardback), ISBN: 9780190077938

The edited book, Changing trends in China's inequality: Evidence, Analysis, and Prospects is a comprehensive, evidence-based, systematic study of various issues of the evolving inequality in China. It draws on the China Household Income Project (CHIP) and uses CHIP survey datasets. Twelve chapters are included in the book, with the overarching key conceptions and main findings synthesized in Chapter 1, followed by studies of dynamic trends in household incomes and inequality nationwide in China (Chapter 2). The first two chapters lay the foundation for the remaining chapters of the book. Various critical perspectives of the inequality issue in contemporary China are investigated and delineated in the book, including the emergence of "Global Middle Class" in China (Chapter 3); the distribution as well as increasing inequality of wealth (Chapter 4); the effects of introduced social policy programs on the economic distances (Chapter 5); the poverty and inequality in rural society (Chapters 6 and 7); the long-term trends of household income, poverty and consumption inequality in urban China (Chapters 8 and Chapter 9). Furthermore, the remaining three chapters provide lens upon some selective topics derived from above chapters, including the income and poverty gaps between Han and ethnic minorities in rural China (Chapter 10); the wage gap between genders in urban China (Chapter 11); and the minimum-wage policy's effect on the wage distribution in urban society (Chapter 12).

Given the book structure and my own research interests, this review gives emphasis on the first nine chapters, and aims to discuss the main viewpoints and arguments emerged in the book, and to resynthesize critical comments gearing toward rich research debate and discussion rooted in the broader research domain of "Inequality in the contemporary China".

In Chapter 1, Changing Trends in China's Inequality: Key Issues and Main Findings, the starting point of this book is presented via several critical questions, typically including whether the Chinese National Bureau of Statistics estimates of inequality are accurate, whether the decline of inequality in China is only temporary or continuous, and what are the underlying factors contribute to the inequality decline in China? Also, the data sources (CHIP datasets) and some key definitions of the empirical data employed across the book are described clearly at the beginning of Chapter 1, which helps to set the tone for evidence-based investigation of the book. Besides, I appreciate the review of recent economic and policy developments in this chapter, including the pro-rural (huinong) programs and rural poverty alleviation policy, which have a detailed and appealing style.

In Chapter 2, Overview: Incomes and Inequality in China, 2007-2013, the authors argued that the reforms since 1978 in China have shaped the transformation from a centrally planned society to a market-based economy, resulting in rapid economic growth, substantial structural changes, and increasing living standards shared by the Chinese citizens. However, the inequalities in the whole society began to increase till they peaked in 2008-2009, then progressively declined, and in 2015 returned to the 
inequality level observed during the early 2000s. This chapter investigates the recent decline of this inequality by employing the CHIP data during 2007-2013. The authors conclude their findings with the facts that the rural-urban income gap narrowed during the surveyed period. I would expect more discussion about the underlying factors or contributors toward this declining urban-rural income gap in China, the implications of these underlying factors can provide valuable decision-making references toward a more harmonious society.

Chapter 3, China's Emerging Global Middle Class, reviews comprehensively the conception of "middle-class" and its specific implications rooted in the Chinese context, for which the typical arguments and debates from the perspectives of sociology, economics, business, housing, and home ownership are critically discussed. Also, the typical characteristics (features) of the middle-class comparing to those of the other classes are investigated, for example "the middle class earned most of its income from wage employment and was less involved in business and self-employment than the poorer classes, i.e. China's middle class is a salaried rather than an entrepreneurial class" (97), "the education levels were noticeably higher among adults in the middle class than among those in the lower and poor classes" (99), and for the political status, "middleclass" present a higher percentage of Chinese Communist Party membership (102). The authors have also made some predictions in terms of the proportion of households being classified as middle-class in China. Though these review and discussion are vivid and detailed, I would expect the authors to elaborate more on the impacts of the emerging middle-class in China, from both perspectives of national and international, for which various dimensions and facets can be incorporated.

In Chapter 4, The Increasing Inequality of Wealth in China, the authors not only delineate the enlarging inequality of wealth in the contemporary Chinese society, also attempt to discuss the underlying factors that contribute to the concerned phenomenon. With evidence-based analysis, the authors point out that the skyrocketing housing prices have a significant impact upon the widening of wealth distribution and inequality in China. Although I am happy to see the authors mentioning slightly the policy recommendations toward narrowing the wealth inequality in the society, more detailed and in-depth discussion upon policy implications by drawing on preceding evidence and findings would be highly appreciated.

Chapter 5, Social Policy Reforms and Economic Distances in China, applies CHIP data in examining the effects of a series of social policy reforms (such as the establishment of social insurance system and the expansion of health insurance) upon inequality in the Chinese society (including urban and rural residents and migrants). The authors found that for urban households, social policy of pensions in urban areas has consistently contributed to narrowing the economic inequality; whilst supplementary income and inkind benefits have significant role in redistributing the social benefits in rural sectors. However, more valuable proposals upon how to prevent the increase of income inequality and further promote the balancing act between economic development and social harmony are highly expected following the analysis in this Chapter, given the unique blend of socialist rule and state capitalism of China.

Chapter 6, Public Policy and Long-Term Trends in Inequality in Rural China, and Chapter 7, New Patterns in China's Rural Poverty, focus on the inequality issues in rural China. Particularly, the authors argued in Chapter 6 that "When examining appropriate policy interventions to reduce rural poverty and income inequality, it is crucial to estimate the impact of specific public transfers according to their geo-economic characteristics" (196). The readers would expect more detailed explanation and pilot case studies to support policy recommendation. Similarly, the viewpoint in Chapter 7 is that "it is difficult for 
nuseholds in the mountainous areas to overcome poverty. The design of suitable polities should take these issues into consideration" (232). In this regard, tailor-made policy instruments toward the poverty alleviation in the less-developed mountainous areas such as Southwest China are needed, which requires more research efforts to be devoted. Additionally, the authors argued that "In an attempt to solve China's poverty problems, the Chinese government declared the goal of not worrying about food and clothing, and of guaranteeing compulsory education, basic medical care, and housing by the year 2020" (233). This raises questions as to how these series of development goals have been achieved. Given the current time point, more recent evidence is needed to track development trajectories.

Chapter 8, Unequal Growth: Long-Term Trends in Household Incomes and Poverty in Urban China, and Chapter 9, Consumption Inequality in Urban China, target the inequality issue in urban society of China. Urban China is captured as the home to large number of rural-to-urban migrants without urban "hukou" who earned incomes lower than those of the urban-registered residents. Consumption-wise, housing privatization, and the rising costs of housing had constrained the consumption of the majority of Chinese urban households at the bottom- or lower-middle-income stratum, given the pursuit of saving for housing purchases.

Following my reading, I find Changing trends in China's inequality overall wellstructured; the arguments are based on substantial empirical data. The book covers a wide range of topics concerning inequality in contemporary Chinese society. The authors offer six "cross-cutting findings", namely: (1) Income inequality in China declined during the study period (2007-2013); (2) urban-rural income gap has also declined; (3) regional disparity-income gaps between the East, West, and Central China are no longer a major contributor of the inequality nationwide; (4) household wealth grew remarkably whilst was distributed unequally; (5) household income increase makes a growing number of Chinese households to attain levels of income comparable to those of middle-class households in the Global North; and (6) absolute poverty in China continued to decline to a relatively low level. The book offers a valuable reading for scholars interested in the Chinese socioeconomic and political development, particularly for those who are interested in the inequality between urban and rural sectors, between different social strata, between genders, and between Han and ethnic minorities. However, the fact that the empirical investigations are limited by the end of 2013 suggests more recent evidence would be needed to track the recent development trajectories. Moreover, more detailed and in-depth discussion upon policy implications by drawing on the evidence and findings in each chapter are highly expected. These tailor-made policy recommendations and implications are critically important - a piece of good academic work should attempt to have potential influence and impact upon the evolving real world.

Yitian Ren Department of Planning and Environmental Management, The University of Manchester, Manchester, UK Q yitian.ren@manchester.ac.uk (D) http://orcid.org/0000-0003-1638-5534 